British Journal of Marketing Studies (BJMS)

Vol. 8, Issue 1, pp.47-67, February 2020

Published by ECRTD- UK

Print ISSN: 2053-4043(Print), Online ISSN: 2053-4051(Online)

\title{
SERVICE QUALITY AND SPEED OF SERVICE IN THE NIGERIA POLICE FORCE: THE ROLES OF SERVICOM
}

\author{
*OLOWE, Temitope Sunday ${ }^{1}$ and OGUNODE, Philips Olatunde ${ }^{2}$ \\ Department of Marketing, School of Business, Federal Polytechnic, PMB 5351, Ado-Ekiti, \\ Ekiti State, Nigeria \\ *Corresponding author: olotemitope@gmail.com; +2348032196955
}

\begin{abstract}
This paper focused on service quality and speed of service in the Nigeria police force: the role of service compatibility (SERVICOM). The study specifically examined the effect of SERVICOM on the quality of service as well as timeliness of service in the Nigeria police force. Descriptive survey design was adopted through which structured questionnaire was used to collect data from the field. The population of the study comprised of all police officers from all ranks and files within Ekiti and Ondo States as well as consumers of police services. Convenience sampling technique was used to select 4,000 respondents which included 2,000 police officers from different ranks and files as well as 2,000 consumers of police services within the two states. Available data were analysed with the use of descriptive statistics as well as $t$-test for the formulated hypotheses. Findings showed that SERVICOM, if fully implemented, has significant effect on both quality and timeliness of service in the Nigeria police force. It was therefore recommended among others that an enhanced salary structure which will be globally competitive should be introduced into the Nigeria police force so as to enhance the quality of their services.
\end{abstract}

KEYWORDS: service, service quality, speed of service, SERVICOM, Nigeria police

\section{INTRODUCTION}

Prior to the introduction of the SERVICOM by the former President Olusegun Obasanjo, there were perceived dissatisfaction from various individuals and corporate institution with regards to the quality of service provided by the government. Government business in Nigeria had almost become no one's business and the key metric of customers' satisfaction which is quality service delivery was almost non-existent. For the Nigeria police, Osayande (2008) contends that her foundation was weak and it has affected the task of effective policing. Series of concerted efforts had been made by previous administrations to reform the Nigeria police force but it seems that little or no meaningful impact had been made. It was the believe of the government that the introduction of SERVICOM will lead to better customers' satisfaction through improved service delivery but this seems not to be so in the case of the Nigeria police force.

\section{Statement of Problem}

Nigeria's legendary poor security situation occasioned by the inefficiency of the Nigeria Police Force has been discussed at various fora over the past 30 years, even before the military coup of 
Print ISSN: 2053-4043(Print), Online ISSN: 2053-4051(Online)

$31^{\text {st }}$ December, 1983 (Global Security, 1983). For these past decades, the Global security watch has rated the Nigeria Police very low. The Nigeria Police Force is rated high among the most corrupt, poorly equipped, poorly remunerated and gross violators of fundamental human right globally (Global Security, 1983).

In most police stations in Nigeria, the care free attitude of policemen seem to be taking a huge toll on timely prevention, combating and investigating of crime. Starting from the point of reception where complaints are lodged, to the waiting time for taking statements, through crime investigations to the point of arrest/prosecution of suspect; perennial complaints of delays, seem to have bedeviled the Nigeria Police.

In like manner, poor service delivery which seems to be the bane of the Nigeria Police is due to poor attitude to work, corruption, dishonesty and bureaucratic bottlenecks in the Nigeria Police Force (Osayande, 2008). Good service delivery is an imperative and panacea to human right violation, corruption, dishonesty and delay in providing quality services. Nigerians whom the policemen were employed to serve cannot enjoy the service when these ills persist in the Nigeria Police Force. On account of these challenges, clients' satisfaction and patronage, public confidence and public rating seem to make the Nigeria Police to rank low.

Administratively, it could be deduced that these challenges majorly bothered on the management of both the materials and human resources meant to direct resources of the Nigeria Police Force towards delivering quality services to the public. According to Flippo (1981), human resources management is the planning organizing directing and controlling of the procurements, development, compensation, integration, maintenance and separation of human resources to the end that individual, organization and societal objectives are accomplished. If this is true, then, it could be safely stated that the Nigeria Police Force, just like most of the other public institutions could be tied to the failed human resources management process. In spite of all these problems, there is little or no systematic study that have been conducted to unraveled factors that are responsible for poor service delivery by the police despite the introduction of SERVICOM benchmark into the NPF. In spite of the magnitude of these problems which are imminent in the Nigeria Police Force, research on how to nip them at the bud appears to be out of sight in literature. It is sequel to the above that the current study examines the roles of SERVICOM on service quality and speed of service in the NPF.

\section{Research Objectives}

The general objective of the study is to examine effect of SERVICOM on service quality and speed of service in the Nigeria police force. The specific objectives of the study are to:

-Investigate the effect of SERVICOM on the quality of service provided by the Nigeria police force.

-Examine the effect of timeliness of service on the service delivery of the Nigeria police force. 
British Journal of Marketing Studies (BJMS)

Vol. 8, Issue 1, pp.47-67, February 2020

Published by ECRTD- UK

Print ISSN: 2053-4043(Print), Online ISSN: 2053-4051(Online)

\section{LITERATURE REVIEW}

\section{The Concept of Service}

Among the numerous definitions given on service, Kotler (2000) defined service as any act, performance or experience that one party can offer to another. According to Lovelock and Wirtz (2004) "Services are economic activities that provide time, place, form utility, problem solving while bringing about a change in, or for, the recipient of the service". Services possess the characteristics of perishability, intangibility, inseparability and heterogeneity. Services deliver the intangible value like knowledge, utility or care and convenience to the party who needs it. Due to the emergence of new service organizations playing similar roles, it is easy for one security agency to copy new innovations from another. This has caused the unhealthy competition and rivalry that are sometimes witnessed among service organizations in Nigeria. This is the reason why the authority in charge of the Nigeria Police Force keep formulating and preaching about policies that will ensure quality and effective service delivery by men of the Nigerian Police Force. Some of these messages include: police are your friend, volunteer useful information to the police; help the Nigerian Police to help you, bail is free, etc. All these aim at creating good public image about the agency and improve the confidence of the masses in the Nigeria Police.

To know how to provide quality service, there is the need to understand the concept of quality service. In an attempt to define service quality, the definition of customer service and quality must first be given. Turban (2002) defined customer service as "a series of activities designed to enhance the level of customer satisfaction-that is, the feeling that a product or service has met the customer expectation". Quality on the other hand has been defined by Fox (1993) as the conformance to requirements, specifications and fitness for the purpose of use. Putting the two together, quality service or service quality can be defined as a series of activities designed in conformance to requirements and specifications of the customer in order to ensure customer satisfaction. Parasunaman et al. (1994) postulated that achieving quality customer service entails conformance to the customer's specifications. They further opined that it is a conscious effort to continuously learn about the expectations and perceptions of customers and non- customers in order to improve the service. In this regard, quality can be said to be the meeting of the needs and expectations of customers.

Owusu-Frimpong (1999) contends that the attitude of the service organization can help the customer to evaluate the quality of service being offered to them by the organization. A receptive attitude of the police is a key ingredient for giving customer $\{$ the public $\}$ positive image about the agency and the services provided. Dei-Tumi (2005) argued that customer service is attitude, not a department. He further opined that it is the attitudes towards the customer that will help the company create and keep their customer for life. Owusu-Frimpong (1999) further admonished that, the physical environment regarding the infrastructure, the design and the general atmosphere are equally taken into account by customers when assessing the quality of service of an organization. Similarly, the duration of service delivery gives both positive and negative impression to customers. A fair handling of cases for instance, may give a good impression about the Nigeria Police Force that its services are of high quality. 
Print ISSN: 2053-4043(Print), Online ISSN: 2053-4051(Online)

\section{Service Quality}

Fogli (2006) defined service quality as "a global judgment or attitude relating to a particular service; the customer's overall impression of the relative inferiority or superiority of the organization and its services. Service quality is a cognitive judgment. ISO 9000 (2005) also defined quality as the extent to which a bunch of inbuilt features (relating to products, a process or a system) meet the requirements. The inbuilt features can be physical, sensory, behavioral, temporal, ergonomic or functional, whilst requirements are the stated need or expectations, be it implied or obligatory. Parasuranman et al. (1991) noted that quality is the meeting of the needs and expectations of the customers. Therefore the yard stick for determining service quality is the expectations of customers and not the policy of the Nigeria Police Force. This view moreover, has been asserted by Ting (2004) and Jamali (2007).

Hossain and Leo (2009) stated that most research has indicated that service quality has been increasingly recognized as a critical factor in the success of any business with the Nigeria Police Force being in exception. Service quality has been widely used to evaluate the performance of service organizations \{Cowling and Newman, 1995\}. Dawes and Swailes (1999) also opined that the service providers understand that customers will be loyal if they provide greater value (quality services) than their competitors. It was also argued that high profits could only be earned if they are able to position themselves better than competitors within specific markets as postulated by Davies et al.(1995). Consequently, Chaoprasert and Elsey (2004) also emphasized the need to focus on service quality as a core competitive strategy.

In measuring customer satisfaction with service quality, it is significant to examine the service quality concept, its importance and the dimension it has. Service quality had been a difficult concept to define and that has aroused considerable interest and debate in the research literature. This is because the meaning of quality can be referred to in many attribute such as the experience of the service encounters, or "moments of truth", the evidence of service; image; price and so on. These form the customer's overall perception of quality, satisfaction and value (Zeithaml and Bitner, 1996).

There are a number of different "definitions" as to what is meant by service quality. Since service quality is basically defined from customer perspective and not the manufacturers, it is usually referred to as customer perceived quality. The concept of consumer perceived quality (CPQ) was first defined by Gronroos in 1990 as the confirmation (or discontinuation) of a customer's expectations of service compared with the customer's perception of the service actually received. One definition that is commonly used defines service quality as the extent to which a service meets customers' needs or expectations (Asubonteng et al., 1996). Parasuranman et al. (1988) supported the same view, as they defined the concept of service quality as a form of attitude related, but not equivalent to satisfaction, that results from a comparison of expectation with perceptions of performance. Expectations are viewed as desires or want of customers i.e. what they feel a service provided rather than offered (Parasuranman et al., 1988). Although service quality has been perceived for a long time to be an outcome of customer cognitive assessment, recent studies confirm that service quality involved not only an outcome but emotions of customers. It is argued 
Print ISSN: 2053-4043(Print), Online ISSN: 2053-4051(Online)

that "during the consumption experience, various types of emotions could be elicited, and these customer emotions convey important information on how the customer will ultimately assess the service encounter and subsequently, the overall relationship quality" (Wong, 2004).

Edvardsson (2005) maintained that customer perception of service quality is beyond cognitive assessment as it is formed during the production, delivery and consumption of services and not just at the consumption stage. This is made possible as customers play their roles as co-producers by carrying out activities as well as being part of interaction influencing both process quality and outcome quality. On the role of service quality, Berry et al. (2002) emphasize on managing the total customer experience. Therefore an emotional reaction is part of a quality and favourable experience (Homburg and Giering, 2001). This is consistent with the finding of Mono and Oliver's (1993) on utilitarian and hedonic consumption judgment, who argues that "satisfaction is naturally tied to cognitive judgments and to affective reactions elicited in consumption" (Mano and Oliver, 1993). Wong (2004) found that negative emotion have a strong effect on satisfaction with quality than positive emotions.

The concept of service quality from the customer perspective, that is perceived service quality, is not a mistake simply because in the words of the gurus "the customer, of course, perceives what he or she receives as the outcome of the process in which the resources are used i.e. the technical or outcome quality of the process. But he or she also and often more importantly, perceives how the process itself functions, i.e. the functional or process quality dimension. Thus, the technical quality and functional quality dimensions of perceived service quality emerge." (Gronroos, 2001).

\section{Consequences of Poor Quality Service}

Finn and Lamb (1991) commented that, it was important for management to recognize the different ways that the quality of a firm's product or service can affect the organization; and to take these into account in developing and maintaining a quality assurance programme. They outlined some of the major ways that poor quality affects an organization to include the following:

(i) Loss of Business: Failure to devote adequate attention to quality can damage a profit oriented organization's image and lead to a decreased share of the market, or it can lead to increased criticism on the part of consumers.

(ii) Liability: Poor quality may create potential liability for a firm due to damages or injuries resulting from either faulty design or poor service

(iii) Productivity: Productivity and quality are often closely related. Poor quality can adversely affect productivity during the production process through rework. Conversely, improving and maintaining good quality can have a positive effect on productivity.

(iv) Costs: Poor quality service by the organization. They include payments of discount to customers to offset the inferior quality, rework costs, warranty cost, replacement cost.

\section{Excellent Customer Service}

Customer service is an organization's ability to supply their customer's wants and needs. Excellent customer service is the ability of an organization to constantly and consistently exceed the customer's expectations (John, 1999). Therefore, to be able to consistently exceed expectations, 
Print ISSN: 2053-4043(Print), Online ISSN: 2053-4051(Online)

there should be the recognition that every aspect of the business has an impact on customer service. Improving customer service involves making a commitment to learning what our customers' needs and wants are and developing action plans that implement customer friendly processes (Kotler and Amstrong, 2006).

The competition among the security agencies now is keen with the sole aim of being in the good record of the Federal Government as well as the Nigeria Populace, hence the need to ensure quality customer service with the Nigeria Police Force in order to justify its existence in the market. It is perceived that the public of late is more knowledgeable, demanding, analytical and aware of his rights and as such would not like to be treated anyhow or given sub standard service. The effort to provide the customer with all the satisfaction that he or she requires has become an important component of the agenda of every organization.

A customer of the Police is any person who directly or indirectly has an encounter with the organization either as a complainant or as a suspect. It is improbable that a well equipped, well trained and well motivated police force would perform significantly better, as long as the society remains decadent. Therefore, for the Police to perform, it is imperative that the society ills are addressed. In enhancing quality service delivering in the police, the citizen (customer) needs to cooperate with them in apprehending criminals who threaten the efficiency of the Nigeria Police Force.

Although a lot of Nigerian do not volunteer useful information to the Nigerian Police that could lead to efficient service delivery. The reason is not far-fetched, as most volunteers become prime suspect most especially when the suspected criminal(s) could not be apprehended. The issue of non-cooperation with the police was further illustrated with a case of a bank official who reported that a large amount of money was missing from the bank's vault. When the police said it would possibly arrest some suspect, the bank chief quickly announced his decision to discontinue with the case because of the adverse effect such arrests may engender, which he believed would not be in the overall interest of the bank.

Over the last decade, there has been a rise in the number of Para-military agencies which have been empowered constitutionally to carryout similar functions as the Nigeria Police Force. For example, the Nigerian Security and Civil Defense Corps (NSCDC) as of today perform virtually all the tasks that the Nigerian Police were instituted to perform. This, in a way, affects the popularity of the Nigeria Police Force, hence there is need for them to woo the citizens and create better image for the force lest they may be less preferred by the citizens.

\section{Complaints in Service Organization and its Management}

When the gap between customer perception and expectation is significant, complaints arise. Customer complaints are one of the most important aspects of business operations that need management control, yet they are often neglected and treated as a nuisance by many organizations (Warland, 2002). Nevertheless, they have considered value for several reasons. 
Print ISSN: 2053-4043(Print), Online ISSN: 2053-4051(Online)

Although there will always be a small number of "frivolous" complaints, a complaint usually highlights something that has gone wrong with a part of the overall marketing operations. Whatever the reason, the sensible marketer will want to know exactly what went wrong so that remedial action may be taken. The way in which a complaint is handled is often seen by customers, and their many contacts, as an acid test of the true quality of support. What is more, it is also a powerful reminder to the organization's own staff of just how important quality is. Customers who complain are usually loyal customers (those who are not loyal tend to switch to another supplier) and will continue to be loyal and valuable customers as long as their complaint is handled well.

A survey conducted by the United States Department of Commerce, customer's complaint Division in 2003, indicated that $85 \%$ of customers are likely to continue to patronize companies which addressed their complaints, while $10 \%$ of the consumers said they are not too sure of patronizing the products of the company even when their complaints were addressed. The remaining $5 \%$ of consumers said they were not likely to continue to patronize a company's product with a defect even when it is taken care of. Tax and Brown (2004), also expressed similar view by saying that only 5 to 10 percent of dis-satisfied customers choose to complain- the rest simply switch companies or make negative comments to other consumers.

The above indicate that consumers are most likely to continue to patronize a company's product or service if their complaints are well handle. This indicates therefore that consumer complaints should be positively encouraged. One of the surest signs of a bad or declining relationship with a consumer is the absence of complaints from customers. No customer is ever that satisfied, especially over an extended period of time; the customer is either not being candid or not being contacted, (Best, 2001). This is not the same as saying that the reasons for complaints should be encouraged. But assuming that problems have occurred despite the organization's best efforts, it should put nothing in the way of any customer who wants to complain. The main problem lies with some customers who do not complain and instead, change to another supplier rather than the few who abuse the complaint system (Ijewere, 2009).

Best (2001), said further that many business have established toll free numbers so that customers can report problems easily and at the company's expense. American Express for example, has installed such lines and estimated that it achieves response more quickly and at 10 to 20 percent of the cost of handling correspondence. General Electric, another American firm has even gone further by providing a round the clock, centralize, expert, general support service i.e. anyone who has a query not necessarily a complaint-about any of GE'S products may call free of charge. In the case of Nigeria many big organizations locate suggestion boxes in strategic areas where customers can drop their complaints. Besides, customer service divisions are also created by these big firms to address customer's complaint. Some of these companies include the Nigerian Airways, Nigeria Bottling Company, Nigeria Brewery PLC, Unilever and banks generally.

The first rule is that all complaints should be carefully handled by painstakingly controlled and monitored procedures. Complaints must be handled well and must be seen to be handled well by 
the complainers and by the organization's own staff. The second and most important rule is that the complaint should be fully investigated and the cause remedied. Complaints are only symptoms; the diseases needs to be cured (Hyman, 2001). There may be an understandable temptation to overlook complaints until they reach a significant level, but holding off until the complaints reach this pain threshold usually means that they have already become damaging to the organization's image .

The ability to record and deal with consumer complaints as they come by organizations will go a long way to guarantee their continuing existence in business. The business environment is becoming more sophisticated by the day. It is only companies that can provide consumers with goods and services that can give them satisfaction, they will continue to patronize and be loyal to. The ability of companies to provide goods and service to the consumers that can command satisfaction; will reduce their attitude to complain. Consequently, consumer complaints are very important to the survival of an organization.

Three common coping responses by customers have been distinguished: (a) Avoidance (b) Emotion focused and (c) Problem focused, (Stephens and Gwinner, 2003). The first response, avoidance, is common among customers who conclude that potential gains of taking action are unlikely, thus complaining or taking action of any sort is simply not worth the effort. They cope by ignoring the situations and avoiding the provider. If there are other providers, they will vote with their feet and switch. Customer complaint departments are unaware of the dissatisfaction of avoidant customers. Emotion focused complainants are also unlikely to contact the customer complaint department, because they cope by directing their attentions to their emotions, minimizing the errors of the provider, blaming themselves for the problem, empathizing with the provider employees who caused the difficulty, will direct efforts outside of themselves, to contact either the provider or a third party about the problem. Provider complaint department personnel will hear from some of the problem focused customers.

A common myth is the customers act out of rational self- interest. In fact, customer dissatisfaction is a more emotional than a cognitive or rational response. This fact emerges starkly from data on aggregate or individual trends in consumer complaints. Numerous surveys have highlighted the fact that the majority of dis-satisfied customers never complain. Estimates of under reporting of complaints are dramatic, running as high as $95 \%$ in some studies, (TARP, 2000). One can safely estimate that a few as one third of dis-satisfied consumers will voice their complaint directly to the provider, (Stephens and Gwinner, 2002). The percentage of complaints logged with third-parties is low as few as $5 \%$ in a recent study comparing US and South Korean consumers (Liu and McClure, 2003).

Dissatisfied consumers tend to adopt one of three modes to express their dissatisfaction (Hansen et al., 2001). Some will voice their complaints; others will retaliate against the provider, for example, by spreading negative information about the provider through word of mouth to friends, family members, neighbors' and their community while the third group simply switches providers. Though the case of the Nigeria Police is such that the citizens have no other option than to voice 
since they have been empower by the government to handle crime related issues. Past research has revealed that managers are not always receptive to customer complaints. However, an analysis of the substance of complaints in the finance sector shows relatively few frivolous or non meritorious complaints (SOCAP-TARP, 2002).

Similar analyses have shown that most claims are suitable for resolution in house by the provider, for example through an internal dispute resolution program. This is particularly true of most unintended institutional errors, such as complaints about fees charged contrary to terms of a contract, mistakes in transaction, fee discrepancies, loss of documents e. t. c which comprises the bulk of the complaints. Past studies highlighted the fact that customer complaint behavior is not a matter of a straightforward cause effect relationship. Multiple factors interact in complex ways to influence the likelihood that customer will voice and lodge an internal complaint (Jacoby and Jaccard, 2001). First, consumers are often ignorant of the avenues of recourse that may exist within any given organization to handle complaints. In some instances, this is because managers are afraid of a deluge of complaint, so do not give the complaint channels a high profile, or they want to avoid the word "complaint", so customers have to wend their way through obscure euphemisms, such as "customers service management" or "the information hotline".

For customers who are more alienated from the market place than others, avenues that seems obvious to others will elude them, (Signh and Wilkes, 2002). Another impediment to customers is that the complaint process may not be readily manageable. For instance, consumers may have to write a formal letter to initiate a complaint, enclosing documentation, and to do so within specified time limits of discovering a purported error. All of these features are deterrents, time consuming or orchestrate, and make customers approach the issues of making a complaint with either the process less approachable. Customers approach the issue of making a complaint with either positive, negative or neutral past experience. Past studies of customers who complained about financial service revealed that approximately one third of the customers were satisfied, one third were pacified, and one third remained dissatisfied (SOCAP-TARP, 2000). Customers who have had success in the past in bringing complaints will draw on that experience, and be more likely to complain in the future when the need arises than those customers whose past experience was not as satisfying, (Singh and Wilkes, 2001).

Inexperience or past negative experience may make customers reluctant to complain if they fear that assertiveness of this sort will mark them as unpleasant or unfavorable and lead to a diminution in service. Customers who have been intimidated by the fact that complaint calls were recorded in the past may fear the apparent lack of confidentiality and adversity of these records. They may wonder whether the information will be shared with other providers. When faced with problems, customers respond in different ways. Singh and Wilkes (2001) gave four customer styles in response to service problems which are as follows; (a) passive (b) voices (c) irate and (d) activists. Passive customers take no action. Only complainants seek redress, voicing their claims in writing or by telephone. Irate customers will spread their anger and dissatisfaction by word of mouth to friends, family members and their community. Activists will turn to third party, external interveners to resolve their dissatisfaction, e.g. lawyers, better business bureaus, Ombud office, or 
Print ISSN: 2053-4043(Print), Online ISSN: 2053-4051(Online)

other third party neutrals. Before attempting to promote customer complaints an understanding of factors that reliably predict more customers' complaints is helpful.

\section{Timeliness of service}

In defining timeliness, it is useful to embed a definition within a discussion of two additional concepts- time and working rules. Institutionalists have long suggested an evolutionary, processoriented approach to research, rather than equilibrium based one, as more appropriate for analysis of socioeconomic phenomena. As Henry and Randall (1998) have argued, "the very notion of time and its significance for analysis is determined by what is being examined". Simply put, there is no single meaning of time, no constant that is independent of the questions being addressed and the field of inquiry within which analysis is undertaken.

Some of the more comprehensive studies of time in the Institutionalist tradition have been made by Hayden, (1987) who has similarly argued that time is "not a natural phenomenon; rather it is a societal construct". As a societal construct, different societies have taken very different perspectives on time that have become more complex as societies have become more complex:

In the simplest technological societies, only a few events had to be synchronized in order to facilitate social life. Time existed only when those events had to be synchronized or when historical occurrences had to be recorded. It did not exit the remainder of the day, week, or year. There were no clocks or a sense of time sequencing. Neither was time divided into units such as weeks or hours. With the evolution of nomadic and agricultural societies, socio-technical processes became more complex, thus more synchronization and coordination were needed. Planting, harvesting, and warfare require more refined coordination. In addition, because the seasons became more important to when and where the tribe moved or when crops were planted, the seasons replaced events as the main time instruments.

The regular rhythm of an organized society gave the sense of events passing along a time continuum. However the rate of technological change was so slow that life seemed to be repeating itself from year to year and from generation to generation. Therefore, the time construct was thought to be circular. As new technological combinations began to appear more rapidly, it became obvious that society was changing. Therefore, the time continuum ceased to be circular and began to move forward, finally becoming linear. In the industrial era the clock is not just a measure or symbol of passing time. In the minds of that era, it is passing time both operationally and as conscious proof of the passing of time. The clock's 24 hour per day, 60 minutes per hours and 60 second per minute has given the impression of an evenly divided flowing time to those living in an industrial society.

The integration of science (and the notion of relative time), technology, and holistic science results in another construct; real time (Hayden, 1987). Real time, or system time, refers to the sequential events of a system, rather than to clock time. In real time, the system determines the measurement instrument. Real time is defined in a system context that takes account of the appearance, duration passage and succession of events as they are interrelated with a system. In other words, sequential 
Print ISSN: 2053-4043(Print), Online ISSN: 2053-4051(Online)

deliveries themselves are the "clock" with which to measure time in modern socio-technical processes. What exist in society are duration clocks and coordination clocks selected by society, and the sequencing of events as scheduled by societal patterns. Any uniformly flowing time construct that is independent of a process will, as a consequence, be inadequate for analyzing and planning socioeconomic processes in modern societies (Hayden, 1993). This study recognizes time as the real time through which societal decision making are determined. That is, accomplishing the given task at the right time, at the right place and efficiently.

\section{RESEARCH METHODOLOGY}

The research design is the plan of action conceived by a researcher to answer the research questions in the most cost effective manner (Atijosan, 2010). Survey design was adopted because it gives the researcher the opportunity to sample different opinions and obtain current information from the sampled respondents on the subject matter.

The population of the study is made up of all the Police Officers across the ranks and files in Ondo and Ekiti states of Nigeria. Furthermore, the Nigeria citizens who are the recipients of the services provided by the NPF within the two states also participated in the study.

In determining the sample for the population of Police Officers, convenience sampling (a form of non probability sampling) was used to select 1000 police officers across the ranks and files in each of the States. The Researcher administered questionnaire to Police Officers on duty in all the divisional police headquarters in the two states. Consumer respondents in the study were majorly the clients who have case(s) with the Police as well as motorists at different Police check points as at the time of investigation. By implication, 2000 men of the force took part in the study. Furthermore, quota sampling technique was adopted in selecting the respondents who were administered questionnaire. This technique became inevitable since it gives all the officers across ranks and files and both gender equal opportunity to participate in the study.

Convenience sampling was also used to select 1000 consumer respondents from the two states who took part in the study. In all, 2000 consumer respondents were conveniently selected. Total sample size in this case was 4000. The primary data for this study was collected using the questionnaire and interview. 2000 Police Officers and 2000 consumers of Police services participated in the study. Furthermore, interviews were conducted for the illiterates among the consumers of the services provided by the Nigerian Police Force. The questions include those on personal background of the respondents, that is, age, gender, academic qualification and sex while the other questions were drawn from the core subject matter of the research investigation.

The questionnaires were given to renowned Marketing Consultants and Academics within the country to peruse it and made appropriate suggestion where necessary. In addition, the researchers sought the professional advice of Statisticians and accomplished researchers in the framing of questions that constituted the questionnaire. The reliability of the instrument was ascertained through a trial testing of the instrument which was conducted on 100 respondents, from each state; 
British Journal of Marketing Studies (BJMS)

Vol. 8, Issue 1, pp.47-67, February 2020

Published by ECRTD- UK

Print ISSN: 2053-4043(Print), Online ISSN: 2053-4051(Online)

50 of whom were consumers of Police services and 50 Police Officers. For measuring the internal consistency, Cronbach's alpha coefficient test was applied using the SPSS software to ensure reliability on an alpha level of 0.05 .

The data obtained in this study was compiled and analyzed descriptively using Ms Excel (Microsoft corp. USA) and Statistical Package for Social Sciences (SPSS version 20.0) data analyzing software. Descriptive statistics was used to analyze the research questions while t- test was to test the hypotheses. The level of significance was set at $5 \%$.

\section{DATA ANALYSIS AND DISCUSSIONS}

Four thousand (4000) questionnaires were administered and retrieved on the spot to ensure $100.0 \%$ returns, with all being good and usable for data analysis. The data were processed and analyzed using Ms Excel (Microsoft corp. USA) and the Statistical Package for Social Sciences (SPSS) 23.0 version. The results are presented below.

Data Presentation

Demographic characteristic of Clients

Table 1: Distribution of respondents by Gender

\begin{tabular}{lllll}
\hline Gender & Frequency & Percent & Valid Percent & Cumulative Percent \\
\hline Male & 3348 & 83.7 & 83.7 & 83.7 \\
Female & 652 & 16.3 & 16.3 & 100.0 \\
Total & 4000 & 100.0 & 100.0 & \\
\hline
\end{tabular}

Source: Researcher's Field Survey, 2019

The table above shows that $83.7 \%$ of the total respondents which is equivalent to 3348 are male while $16.3 \%$ which is equivalent to 652 are female. 
British Journal of Marketing Studies (BJMS)

Vol. 8, Issue 1, pp.47-67, February 2020

Published by ECRTD- UK

Print ISSN: 2053-4043(Print), Online ISSN: 2053-4051(Online)

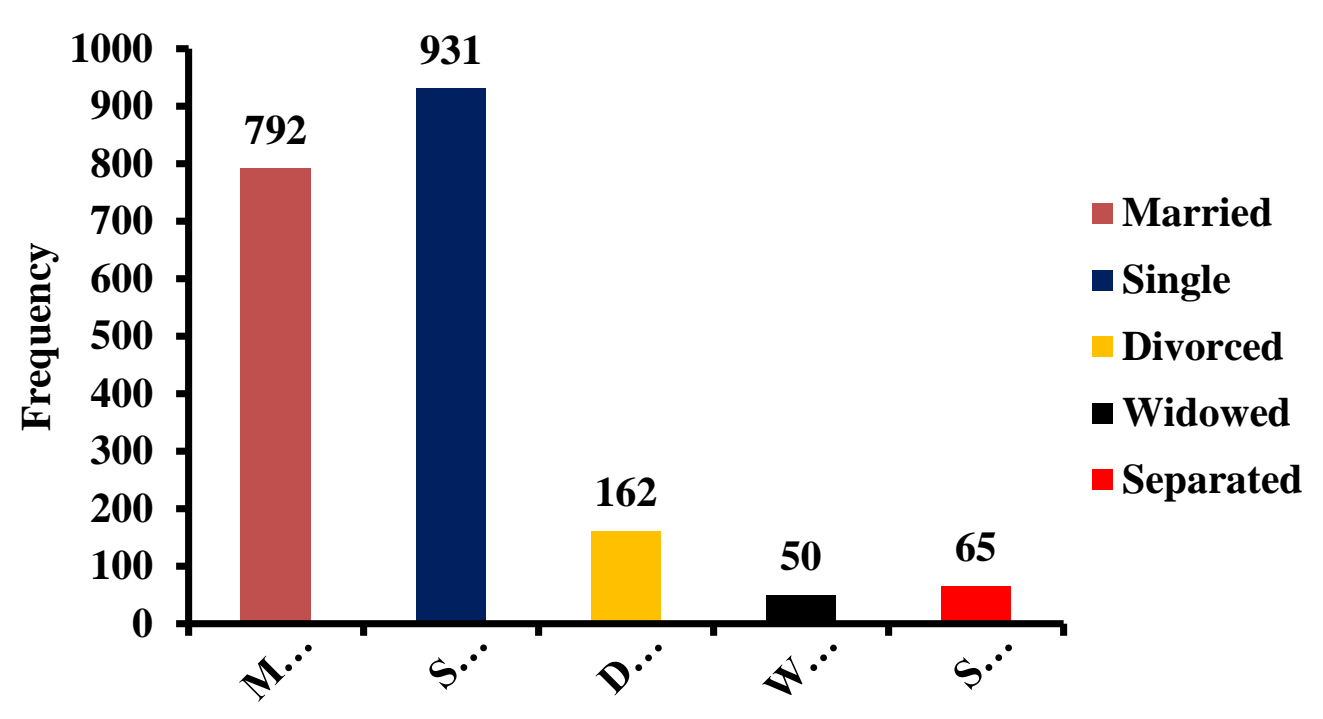

Figure 1: Distribution of clients' respondents by marital status

Figure 1 shows 792(39.6\% of the respondents are married, 931(46.6\%) are single, 162(8.1\%) are divorced while 50(2.5\%) are widowed and 65(3.3\%) are separated.

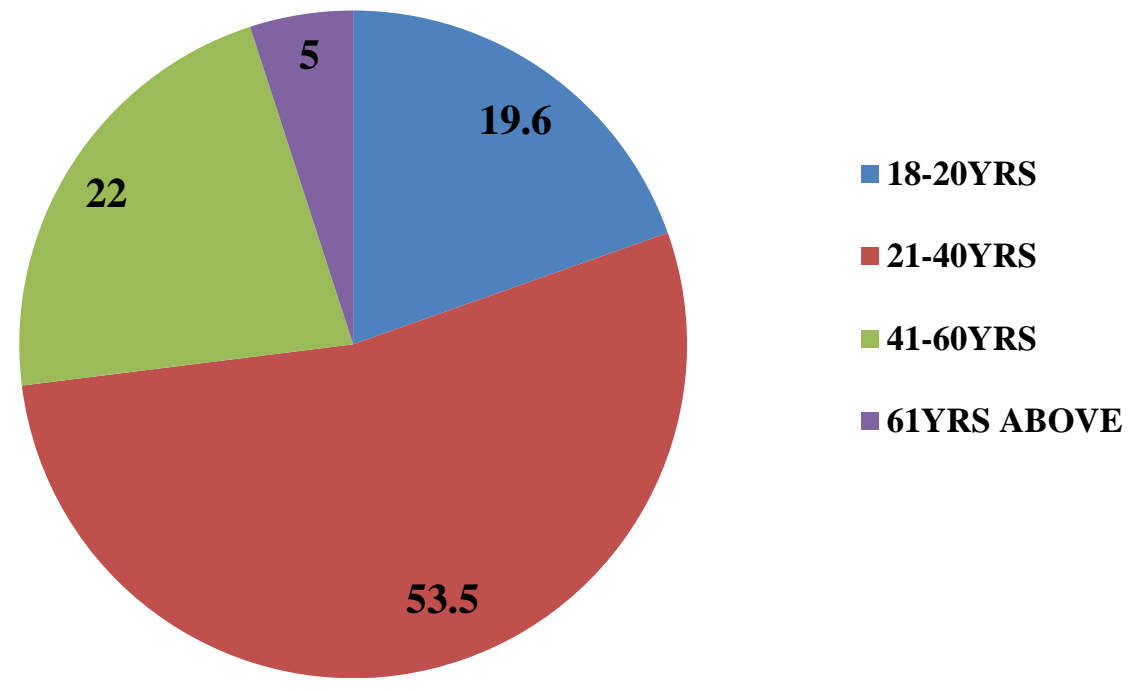

Figure 2: Distribution of Clients' respondents by age

Figure 2 reveals that $19.6 \%$ which is equivalent to 391 of the respondents are between the age of 18-20years, 53.5\% (1070) are between 21-40 years while 22\%(439) are between 41-60 years and $5 \%(100)$ are 61years and above. 
British Journal of Marketing Studies (BJMS)

Vol. 8, Issue 1, pp.47-67, February 2020

Published by ECRTD- UK

Print ISSN: 2053-4043(Print), Online ISSN: 2053-4051(Online)

Table 2: Distribution of Respondents by Educational Qualification

\begin{tabular}{lllll}
\hline $\begin{array}{l}\text { Educational } \\
\text { Qualification }\end{array}$ & Frequency & Percent & Valid Percent & $\begin{array}{l}\text { Cumulative } \\
\text { Percent }\end{array}$ \\
\hline SSCE/NECO & 728 & 18.2 & 18.2 & 18.2 \\
ND/NCE & 1600 & 40.0 & 40.0 & 58.2 \\
HND/First Degree & 1362 & 34.1 & 34.1 & 92.3 \\
Master & 204 & 5.1 & 5.1 & 97.4 \\
Ph.D & 12 & .3 & .3 & 97.7 \\
Other & 94 & 2.4 & 2.4 & 100.0 \\
Total & 4000 & 100.0 & 100.0 & \\
\hline
\end{tabular}

Source: Researcher's Field Survey, 2019

The result in Table 2 reveals that $18.2 \%$ (728) of the total respondents are SSCE/NECO holders, 40\%(1600) are ND/NCE holders, 34.1\%(1362) are HND/First Degree while 204(5.1\%) are Master holders, 0.3\%(12) are Ph.D holders and 94(2.4\%) have other education qualification.

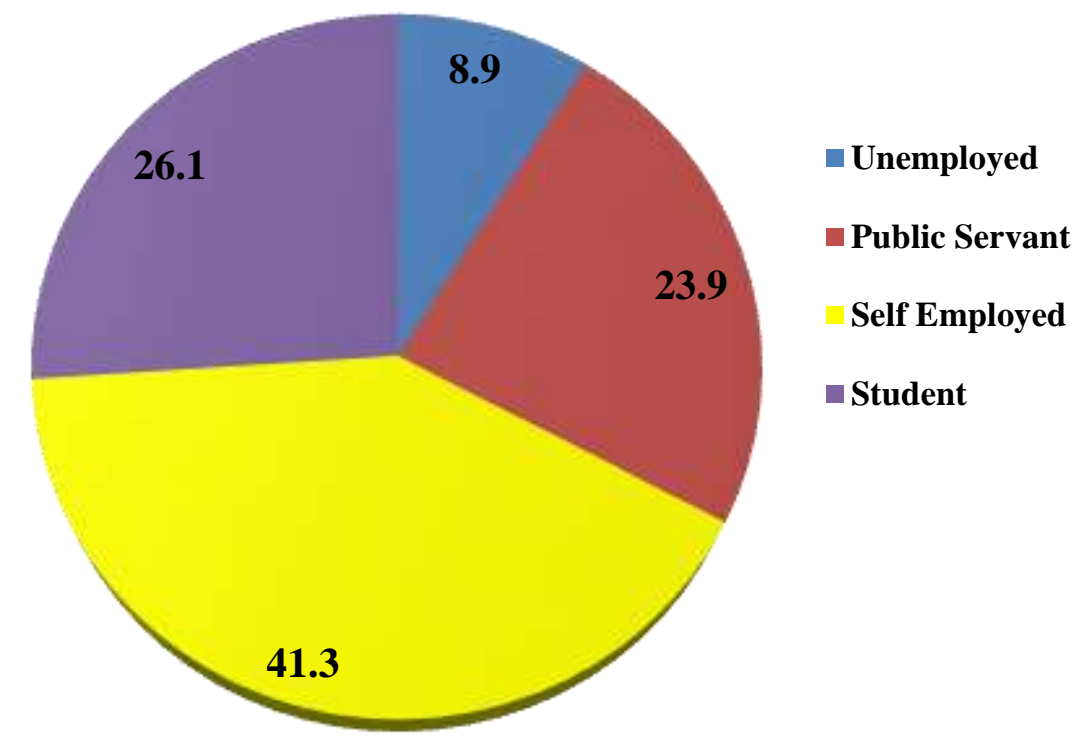

Figure 3: Distribution of Clients' respondents by Occupation

The chart above indicates that $8.9 \%$ (177) are unemployed, 23.9\%(477) are public servant, while $41.3 \%$ (825) are self-employed and $26.1 \%$ (521) are student. 
British Journal of Marketing Studies (BJMS)

Vol. 8, Issue 1, pp.47-67, February 2020

Published by ECRTD- UK

Print ISSN: 2053-4043(Print), Online ISSN: 2053-4051(Online)

Analysis of Research Questions

Table 3: Effect of SERVCOM on the quality of service provided by the Nigeria Police Force

\begin{tabular}{|c|c|c|c|c|c|c|}
\hline $\mathbf{S} / \mathbf{N}$ & ITEMS & SD & D & I & $\mathbf{A}$ & SA \\
\hline 1 & $\begin{array}{l}\text { The service provided by the Nigeria } \\
\text { police force has improved in the past } \\
\text { five years }\end{array}$ & $\begin{array}{l}954 \\
(47.7 \%)\end{array}$ & $\begin{array}{l}820 \\
(41 \%)\end{array}$ & - & $\begin{array}{l}226 \\
(11.3 \%)\end{array}$ & - \\
\hline 2 & $\begin{array}{l}\text { Introduction of free meal to police } \\
\text { officers on duty will enhance service } \\
\text { delivery }\end{array}$ & $\begin{array}{l}332 \\
(16.6 \%)\end{array}$ & $\begin{array}{l}537 \\
(26.9 \%)\end{array}$ & - & $\begin{array}{l}363 \\
(18.2 \%)\end{array}$ & $\begin{array}{l}768 \\
(38.4 \%)\end{array}$ \\
\hline 3 & $\begin{array}{l}\text { Inadequate personnel is a bane of } \\
\text { service delivery in the Nigeria Police } \\
\text { force }\end{array}$ & $179(9 \%)$ & $\begin{array}{l}675 \\
(33.8 \%)\end{array}$ & - & $\begin{array}{l}404 \\
(20.2 \%)\end{array}$ & $\begin{array}{l}742 \\
(37.1 \%)\end{array}$ \\
\hline 4 & $\begin{array}{l}\text { Insufficient allocation and poor } \\
\text { remuneration is responsible for poor } \\
\text { service delivery in the Nigeria Police } \\
\text { Force }\end{array}$ & $\begin{array}{l}830 \\
(41.5 \%)\end{array}$ & $\begin{array}{l}928 \\
(46.4 \%)\end{array}$ & - & $\begin{array}{l}242 \\
(12.1 \%)\end{array}$ & - \\
\hline 5 & $\begin{array}{l}\text { Regular disciplinary action against } \\
\text { erring police officers will improve } \\
\text { service delivery of the Nigeria Police } \\
\text { Force }\end{array}$ & $\begin{array}{l}112 \\
(5.6 \%)\end{array}$ & $\begin{array}{l}651 \\
(32.6 \%)\end{array}$ & - & $\begin{array}{l}234 \\
(11.7 \%)\end{array}$ & $\begin{array}{l}1003 \\
(50.2 \%)\end{array}$ \\
\hline 6 & $\begin{array}{l}\text { Local and International training of } \\
\text { police officers will enhance effective } \\
\text { service delivery }\end{array}$ & $\begin{array}{l}92 \\
(4.6 \%)\end{array}$ & $\begin{array}{l}841 \\
(42.1 \%)\end{array}$ & - & $\begin{array}{l}282 \\
(14.1 \%)\end{array}$ & $\begin{array}{l}785 \\
(39.3 \%)\end{array}$ \\
\hline 7 & $\begin{array}{l}\text { Existence of parallel security } \\
\text { agencies will promote efficiency of } \\
\text { service delivery in the Nigeria Police } \\
\text { Force }\end{array}$ & $\begin{array}{l}130 \\
(6.5 \%)\end{array}$ & $\begin{array}{l}636 \\
(31.8 \%)\end{array}$ & - & $\begin{array}{l}259 \\
(13 \%)\end{array}$ & $\begin{array}{l}975 \\
(48.8 \%)\end{array}$ \\
\hline
\end{tabular}

Source: Researcher's Field Survey, 2019

The table above shows that 954(47.7\%) of the respondent strongly disagree that the service provided by the Nigeria Police force has improved in the past five years, $820(41 \%)$ disagree while $226(11.3 \%)$ agree. $332(16.6 \%)$ strongly disagreed that introduction of free meal to police officers on duty will enhance service delivery, 537(26.9\%) disagreed while $363(18.2 \%)$ agree and 768 $(38.4 \%)$ strongly agree. $179(9 \%)$ of the respondents strongly disagreed that inadequate personnel is a bane of service delivery in Nigeria Police force, 675 (33.8\%) disagreed while 404(20.2\%) agreed and $742(37.1 \%)$ strongly agreed. 830 (41.5\%) strongly disagreed that insufficient allocation and poor remuneration is responsible for poor service delivery in the Nigeria Police Force, 928 (46.4\%) disagreed while 242(12.1\%) agreed.112(5.6\%) strongly disagreed that regular disciplinary action against erring Police officers will improve service delivery of the Nigeria Police Force, 651(32.6\%) disagreed while 234(11.7\%) agreed and 1003 (50.2\%) strongly agreed. $92(4.6 \%)$ of the respondents strongly disagreed that local and International training of police officers will enhance effective service delivery, 841(42.1\%) disagreed while 282(14.1\%) agreed and $787(39.3 \%)$ strongly agreed. $130(6.5 \%)$ strongly disagree that existence of parallel security 
British Journal of Marketing Studies (BJMS)

Vol. 8, Issue 1, pp.47-67, February 2020

Published by ECRTD- UK

Print ISSN: 2053-4043(Print), Online ISSN: 2053-4051(Online)

agencies will promote efficiency of service delivery in the Nigeria Police Force, 636(31.8\%) disagreed while 259(13\%) agreed and 975(48.8\%) strongly agreed. Concentration was on consumers of Police services for the purpose of objectivity of results

Table 4: Extent to which timeliness in service has improved the Nigeria Police Force service delivery

\begin{tabular}{|c|c|c|c|c|c|c|}
\hline $\mathbf{S} / \mathbf{N}$ & ITEMS & SD & D & I & $\mathbf{A}$ & $\mathbf{S A}$ \\
\hline 1 & $\begin{array}{l}\text { The Nigeria Police Force is timely and } \\
\text { courteous in acknowledging client } \\
\text { presence when they lodge complaint at } \\
\text { the information point }\end{array}$ & $\begin{array}{l}215 \\
(10.8 \%)\end{array}$ & $\begin{array}{l}799 \\
(40 \%)\end{array}$ & - & $\begin{array}{l}249 \\
(12.5 \%)\end{array}$ & $\begin{array}{l}737 \\
(36.9 \%)\end{array}$ \\
\hline 2 & $\begin{array}{l}\text { Availability of modern gadgets/ } \\
\text { facilities will improve the } \\
\text { responsiveness of the Nigeria Police } \\
\text { Force to distress calls }\end{array}$ & $\begin{array}{l}136 \\
(6.8 \%)\end{array}$ & $\begin{array}{l}639 \\
(32 \%)\end{array}$ & - & $\begin{array}{l}261 \\
(13.1 \%)\end{array}$ & $\begin{array}{l}964 \\
(48.2 \%)\end{array}$ \\
\hline 3 & $\begin{array}{l}\text { Nigeria Police Force has good logistics } \\
\text { to respond timely to scene of crime }\end{array}$ & $\begin{array}{l}442 \\
(22.1 \%)\end{array}$ & $\begin{array}{l}789 \\
(39.5 \%)\end{array}$ & - & $\begin{array}{l}317 \\
(15.9 \%)\end{array}$ & $\begin{array}{l}452 \\
(22.6 \%)\end{array}$ \\
\hline 4 & $\begin{array}{l}\text { Compulsory documentation at the } \\
\text { information point do hinder quick } \\
\text { response to customers' complaint }\end{array}$ & $\begin{array}{l}249 \\
(12.5 \%)\end{array}$ & $\begin{array}{l}683 \\
(34.2 \%)\end{array}$ & - & $\begin{array}{l}347 \\
(17.4 \%)\end{array}$ & $\begin{array}{l}721 \\
(36.1 \%)\end{array}$ \\
\hline 5 & $\begin{array}{l}\text { The Nigeria Police Force has updated } \\
\text { ICT facilities that enhance timely } \\
\text { response to scene of crime }\end{array}$ & $\begin{array}{l}330 \\
(16.5 \%)\end{array}$ & $\begin{array}{l}707 \\
(35.4 \%)\end{array}$ & - & $\begin{array}{l}344 \\
(17.2 \%)\end{array}$ & $\begin{array}{l}619 \\
(31 \%)\end{array}$ \\
\hline 6 & $\begin{array}{l}\text { Quick release of operational fund (e.g. } \\
\text { fueling) to the Nigeria Police Force will } \\
\text { fast-track their response to distress calls } \\
\text { from their clients }\end{array}$ & $\begin{array}{l}222 \\
(11.1 \%)\end{array}$ & $\begin{array}{l}794 \\
(39.7 \%)\end{array}$ & - & $\begin{array}{l}277 \\
(13.9 \%)\end{array}$ & $\begin{array}{l}707 \\
(35.4 \%)\end{array}$ \\
\hline 7 & $\begin{array}{l}\text { The Nigeria Police Force lack } \\
\text { maintenance culture of their gadgets and } \\
\text { other working equipment }\end{array}$ & $\begin{array}{l}205 \\
(10.3 \%)\end{array}$ & $\begin{array}{l}819 \\
(41 \%)\end{array}$ & - & $\begin{array}{l}196 \\
(9.8 \%)\end{array}$ & $\begin{array}{l}780 \\
(39 \%)\end{array}$ \\
\hline
\end{tabular}

Source: Researcher's Field Survey, 2019

The table above reveals that $215(10.8 \%)$ of the respondents strongly disagreed that the Nigerian Police Force is timely and courteous in acknowledging client presence when they lodge complaint at the information point, 799(40\%) disagreed while 249(12.5\%) agreed and 737 (36.9\%) strongly agreed. 136(6.8\%) strongly disagreed that availability of modern gadgets/ facilities will improve the responsiveness of the Nigeria Police Force to distress calls, 639(32\%) disagreed while 261(13.1\%) agreed and 964(48.2\%) strongly agreed. 442(22.1\%) of the respondents strongly 
British Journal of Marketing Studies (BJMS)

Vol. 8, Issue 1, pp.47-67, February 2020

Published by ECRTD- UK

Print ISSN: 2053-4043(Print), Online ISSN: 2053-4051(Online)

disagreed that Nigeria Police Force has good logistics to respond timely to scene of crime, $789(39.5 \%)$ disagreed while $317(15.9 \%)$ agreed and $452(22.6 \%)$ strongly agreed. $249(12.5 \%)$ strongly disagreed that compulsory documentation at the information point do hinder quick response to customers' complaint, 683(34.2\%) disagreed, while 347(17.4\%) agreed and $721(36.1 \%)$ strongly agreed. $330(16.5 \%)$ of the respondents strongly disagreed that the Nigeria Police Force has updated ICT facilities that enhance timely response to scene of crime, 707(35.4\%) disagreed while 344(17.2\%) agreed and 619(31\%) strongly agreed. 222(11.1\%) strongly disagreed that quick release of operational fund (e.g. fueling) to the Nigeria Police Force will fast-track their response to distress calls from their clients, 794(39.7\%) disagreed while 277(13.9\%) agreed and $707(35.4 \%)$ strongly agreed. Furthermore, 205(10.3\%) strongly disagreed that the Nigeria Police force lack maintenance culture of their gadgets and other working equipment, $819(41 \%)$ disagreed while 196(9.8\%) agreed and 780(39\%) strongly agreed. Concentration was on consumers of Police services for the purpose of objectivity of results

\section{RESULTS AND DISCUSSIONS}

\section{Hypothesis 1}

There is no significant effect of SERVICOM on the quality of service provided by the Nigeria Police Force.

Table 5: t-test showing the effect of SERVICOM and Quality of Service

\begin{tabular}{llllll}
\hline Variables & $\boldsymbol{N}$ & Mean & $\boldsymbol{S D}$ & $\boldsymbol{T}$ & $\boldsymbol{p}$ \\
\hline SERVICOM & 2000 & 55.41 & 9.27 & & $112.610^{*}$ \\
& & & & 0.000
\end{tabular}

$\begin{array}{llll}\text { Service Quality } & 2000 & 36.47 & 8.20\end{array}$

*p<0.05

Table 5 shows that there is significant effect of SERVICOM on the quality of service provided by the Nigeria Police Force $(\mathrm{t}=112.610, \mathrm{p}<0.05)$. The null hypothesis is rejected. Therefore, there is significant effect of SERVICOM on the quality of service provided by the Nigeria Police Force. This showed that if the dictates of SERVICOM are given adequate consideration in the Nigeria Police Force, it would definitely enhance their service delivery.

\section{Hypothesis 2}

There is no significant effect of timeliness in service on the Nigeria Police Force service delivery. 
British Journal of Marketing Studies (BJMS)

Vol. 8, Issue 1, pp.47-67, February 2020

Published by ECRTD- UK

Print ISSN: 2053-4043(Print), Online ISSN: 2053-4051(Online)

Table 6: t-test showing the effect of timeliness in service on service delivery

\begin{tabular}{llllll}
\hline Variables & $\boldsymbol{N}$ & Mean & SD & T & $p$ \\
\hline Timeliness & 2000 & 19.08 & 3.90 & $12.688^{*}$ & 0.000 \\
& & & & & \\
Service Delivery & 2000 & 17.96 & 2.96 & & \\
\hline $\mathbf{p}<\mathbf{0 . 0 5}$ & & & & &
\end{tabular}

Table 6 shows that that there is significant effect of timeliness in service on the Nigeria Police Force Service delivery $(\mathrm{t}=12.688, \mathrm{p}<0.05)$. The null hypothesis is rejected. This implies that that there is significant effect of timeliness in service on the Nigeria Police Force Service delivery. This showed that if timeliness in service is given adequate consideration in the Nigeria Police Force, it would definitely enhance their service delivery.

\section{CONCLUSIONS}

Consequent upon the findings of this study, the following conclusions are drawn:

- $\quad$ The service provided by the Nigeria police force has not improved in the past five years. This is as a result of poor remuneration, inadequate budgetary allocation to the NPF, insufficient personnel, lack of adequate discipline of erring officers, lack of up to date equipment needed to perform their tasks.

- The Nigeria Police Force is timely and courteous in acknowledging client presence when they lodge complaint at the information point but this does not translate into timeliness in responding to the scene of crime when distress calls are put across to them as cases of late responses are imminent in the attitudes of the officers of the NPF.

\section{Recommendations}

This study will in no doubt assist the Nigeria government, policy makers and security chiefs with up to date service delivery strategies required in the discharge of their duties. Arising from the foregoing and the findings of this study, the following recommendations are made:

- $\quad$ This study has shown that the NPF is one of the most poorly remunerated police globally and this is adversely affecting their morale and efficiency. Therefore, there is urgent need to come up with an enhanced salary structure that will be globally competitive and attractive which is capable of inducing performance.

- It is also clear from the finding that the current number of police officers in Nigeria is grossly inadequate and this is partly responsible for some inadequacies experienced in the NPF. The government of Nigeria should develop a road map that will allows yearly recruitment of interested and qualified Nigerians into the NPF until the population of the NPF get to one (1) police officer to forty (40) Nigerians.

- $\quad$ The study revealed that the level of discipline usually meted on erring officers is sometimes not commensurable to the offence committed and this may lead to the reoccurrence of such offence 
British Journal of Marketing Studies (BJMS)

Vol. 8, Issue 1, pp.47-67, February 2020

Published by ECRTD- UK

Print ISSN: 2053-4043(Print), Online ISSN: 2053-4051(Online)

in the near future. Hence, the disciplinary committee of the NPF should fathom out better and stiffer punitive measures for erring officers especially when offences are such that can affect effective service delivery or infringement on the rights of the masses.

- $\quad$ The working gadgets that are currently in use by the NPF are old, limited and sometimes malfunction. Therefore, there is need for general overhauling of these gadgets while they should replaced with new and state of the heart equipment. More importantly, there should be proper maintenance culture of these gadgets when provided with the mandate that they should be strictly used for the purpose in which are purchased.

- $\quad$ The NPF officers should be trained to respond timely to scene of crimes. To ensure this, standby vehicles with drivers should be made available at all the police stations across Nigeria. More importantly, the control room in each of the police stations should be able to monitor and know the activities going within their localities. This will enhance easy identification and response to the scene of crimes.

\section{References}

Asubonteng, P., McCleary, K. J. and Swam, J. E. (1996). "SERVIQUAL Revisited: A Critical Review of Service Quality". Journal of Service Marketing 10(6): 62-81

Atijosan, J. I. (2010). “Marketing Research”, Akure, Boluwatife Press and Publishing (Nig) Limited.

Berry, L. L., and Parasuraman, A. (2002). Marketing Services: Competing through Quality. New York, Free Press.

Chaoprasert, C. and Elsey, B. (2004). Service Quality Improvement in Thai Retail Banking and Its Management Implications, ABAC Journal, 24 (1): 47-66.

Cowling, A. and Newman, K. (1995). "Banking on People, Personnel Review", 24(7): 25-41.

Davies, F., Moutinho, L. and Curry, B. (1995). "Construction and Testing of a Knowledge Based System in Bank Marketing”, International Journal of Bank Marketing, 13 (2): 235-260

Dawes, J. and Swailes, S (1999). "Retention Sans Frontiers: Issues for Financial Services Retailers", International Journal of Bank Marketing, 17(1): 36-43.

Dei-Tumi, E (2005). "Customer Service is Attitude not a Department, Wisdom centre International"

EdVardsson, (2005). “GURU'S VIEW, Service Quality: Beyond Cognitive Assessment Service Sweden Managing Service Quality”. 15 (2): 127-131.

Finn and Lamb (1991). "Consumer Reactions to Product Failure: An Attribution Approach", Journal of Consumer Research, 60, October, Pp. 398-409.

Fogli, L. (2006). Customer Service Delivery. San Francisco: Jossy-Bass.

Fox, M.J (1993). “Quality Assurance Management”, London, Chapman and Hall.

Global Security (1983). Buhari Coup. Http;//www.globalsecurityorg/military/world/war/ Nigeria2.htm.

Gronroos, C. (1990). "Service Management: A Management Focus for Service Competition", International of Service Industry Management, 1 (1) : 9-30

Gronroos, C. (2001). "The Perceived Quality Concept: A Mistake? Managing Service Quality". International Journal of Service Industry Management. $\quad$ 11(3): 150-152. 
British Journal of Marketing Studies (BJMS)

Vol. 8, Issue 1, pp.47-67, February 2020

Published by ECRTD- UK

Print ISSN: 2053-4043(Print), Online ISSN: 2053-4051(Online)

Hansen S. W., Swan, J. E. and Powers, T. L (2001). "Vendor Relationships as Predactors of Organizational Buyer Complaints Styles". Journal of Business Research.

Hayden F.G (1987). ''Evolution of Time Construct and their Impact on Socio-Economic Planning.' Journal of Economic Issues. 21: 1281-1312.

Henry, J. F. and Randall, L.W. (1998). "Economic Time" Jerome Levy Economics Institute Working Paper No 255

Homburg, C. and Giering, A. (2001). "Personal Characteristics as a Moderation of the Relationship between Customer Satisfaction and Loyalty: An Empirical Analysis" Psychology and Marketing, 18 (1): 43-66.

Hossain, M. and Leo, S. (2009). Customer Perception on Service Quality in Retail Banking in Middle East: The Case of Qatar, International Journal of Islamic and Middle Eastern Finance and Management, 2(4): 338-350.

Hyman D. (2001). "Utility Consumer Dispute Settlement": A Regulatory Model of Mediation, Arbitration and Class Advocacy. In M. K. Mills (Ed). Conflict Resolution and Public Westpoort, CT: Greenwood Press 63-76.

ISO 9000 (2005). "Quality Management Systems": Fundamentals and Vocabulary, ISO Retrieved June 15, 2012, from the World Wide Web, http://www.iso.org

Jacoby, J. and Jaccard, J. I. (2001). "Brand Choice as a Function of Information Load" Journal of Marketing Research,

Jamali, D. (2007): A Study of Customer Satisfaction in the Context of a Public Private Partnership, International Journal of Quality and Reliability Management, 24 (4): 370-385.

John, N. (1999). "What is This Thing called Service” European Journal of Marketing 33 (10) : 958-973

Kotler, P (2000). Marketing Management, (10th ed), New Jessy, Prentice-Hall

Kotler, P. and Armstrong, G. (2006). Principles of Marketing, $11^{\text {th }}$ edition, New Jersey Prentice Hall.

Osayande, B. O. (2008). "Factors Inhibiting Police Performance in Nigeria", A Paper Presented at the Occasion of the Retreat with the Theme; "Understanding the Mandate and Operations of the Police Service Commission in the Context of the Rule of Law"

Mano, H. and Oliver, R. L. (1993). "Assessing the Dimensionality and Structure of the Consumption Experience: Evaluation, Feeling and Satisfaction”. Journal of Consumer Research. 20, December. pp 451-466.

Owusu-Frimpong (1999). Patronage Behaviour of Ghanaian Bank Customers, International Journal of Bank Marketing, 17(1): 335-341.

Parasuraman, A., Berry, L. L. and Zeithaml, V. A. (1988). SERVQUAL: “A Multi-item Scale for Measuring Customer Perception of Service Quality”, Journal of Retailing, 64 (1): 12-40.

TARP (2000): "Consumer Complaint Handling in America, a Final Report". Washington, dc: White House Office of Consumer Affairs.

Tax, S. P. and Brown, S. W. (2004). "Recovering and Learning from Service Failure", Sloan Management Review Journal, 58: 75-88.

Ting, D. H. (2004). "Service Quality and Satisfaction Perception: Curvilinear and Interaction effect". International Journal of Bank Marketing, 22(6): 407-420. 
British Journal of Marketing Studies (BJMS)

Vol. 8, Issue 1, pp.47-67, February 2020

Published by ECRTD- UK

Print ISSN: 2053-4043(Print), Online ISSN: 2053-4051(Online)

Warland, R. H. (2002). “A Typology for Consumer Complainers. In R.L Day (Ed.) Consumer Satisfaction, Dissatisfaction and Complaining Behavior", Bloomington, IN: Indiana University, pp144-146.

Wong, A. (2004). "The Role of Emotion in Service Encounters" Managing Service Quality. Journal of Marketing Research, 14(5): 365-375.

Zeithaml, V. A. and Bitner, M. J. (1996): Service Marketing, Integrating Customer Focus across the Firm. McGraw-Hill, New York, NY.

\section{Acknowledgements}

The Management of Federal Polytechnic, Ado-Ekiti is well appreciated for the permission granted in carrying out this research work. Also, the contribution of TETFUND is highly commendable for providing an enabling environment in terms of finance to carry out this research work. If not for the opportunity enjoyed from TETFUND, this research work would have been a mirage. 